\title{
PARTITIVITY AND OBJECT MARKING IN FINNISH AND LITHUANIAN
}

\author{
Asta Laugalienè \\ Vilnius University
}

\begin{abstract}
Lithuanian and Finnish both have alternations in object marking involving the notion of partitivity. In Finnish, the case of the direct object of transitive verbs alternates between the accusative and the partitive. Partitive is the default case for the object of a transitive verb and a special feature is required for the assignment of the accusative. In Lithuanian, the case of the direct object of transitive verbs alternates between the accusative and the partitive genitive. Some functions of the Finnish partitive and the Lithuanian partitive genitive in object marking are identical, but some are markedly different. This paper offers an overview of the factors that have been discussed in the literature as affecting the use of partitive cases, and also a comparison of their relevance and relative ranking in Finnish and Lithuanian.
\end{abstract}

Keywords: partitivity, object marking, partitive, genitive, accusative, Finnish, Lithuanian

\section{Introduction}

The use of 'partitive cases' (called simply 'partitive' or 'partitive genitive') in the case marking of the direct object is an areal phenomenon attested in several groups of languages, both Indo-European (Slavic and Baltic) and Uralic (Finnic) (Koptjevskaja-Tamm 2001: 531-544, 557-564, Ambrazas 2006: 229). Finnish and Lithuanian belong to a wider areal continuum with a rich linguistic and historical background and language contacts (Koptjevskaja-Tamm, Wälchli 2001: 728). Finnic and Baltic were in close contact in the Proto-Finnic era (Larsson 1984: 98; Koptjevskaja-Tamm, Wälchli 2001); the main 
evidence for this comes from numerous words borrowed from Baltic into Finnic, which are not found in the other branches of the Uralic languages (Laakso 2001: 201). Some grammatical features are also common to the Circum-Baltic languages as a whole and are considered to be a result of language contact (Koptjevskaja-Tamm, Wälchli 2001: 674-723).

Several studies (Larsson 2001, Klaas 1996 to mention just a few) have proved that the correspondences of the Lithuanian partitive genitive and Finnish partitive cover a wide semantic-syntactic area. There has also been some discussion about the Baltic influence on Finnic object case alternation. Although it seems likely that, as a result of Baltic influence, the original separative case inherited from Volga-Finnic gave rise to the quantitative opposition in object case marking in early Proto-Finnic (Larjavaara 1991: 380-382), there are different views about how the aspectual functions of partitive marking became grammaticalized in Finnic. Some researchers (e.g. Larsson 1984: 98) believe that this happened because of Baltic influence, while others (e.g. Larjavaara 1991) point out that the aspectual object in Finnic languages is a well-motivated and logical semantic development, although Baltic influence in the early stages is indisputable.

Lithuanian and Finnish both have alternations in object marking involving the notion of partitivity. Finnish has a morphological case that is referred to as the partitive. The meaning of the dedicated Partitive case diverges from the generally assumed partitive concept, which is to be seen as an abstract concept for comparison of the semantics of grammatical forms covering the "part-of-N" (1a) and "amount-of-N" (1b) concepts ${ }^{1}$. The partitive concept comprises two metonymically related subconcepts: the Partitive (N-of-the-N, 1a), and the pseudopartitive (N-of-N, 1b) (Tamm 2014: 91). Therefore, the partitive concept is broader than the notion of a part-whole relationship and includes also the pseudopartitive:

\footnotetext{
1 Further on in the text, Partitive as a dedicated case will be marked with a capital letter to distinguish it from the partitive as a concept. In the same way, the Finnish Accusative and Lithuanian Partitive genitive will be marked with capital letters.
} 
(1) a. Finnish

\begin{tabular}{|c|c|}
\hline nuorin & lapsistani \\
\hline young.suP.NOM & child.ELA.POSs.PL \\
\hline \multicolumn{2}{|c|}{ 'the youngest of my children' } \\
\hline \multicolumn{2}{|l|}{ b. Lithuanian } \\
\hline stikline & vandens \\
\hline cup.NOM & water.GEN \\
\hline a glass of water' & \\
\hline
\end{tabular}

A linguistic Partitive is a grammatical form that is conceptually related to the meaning of the partitive concept and is divided into functional (e.g. aspectual, (2a)), and structural categories (e.g. default case, (2b)), depending on the semantics of the Partitive in the structure of the language at hand (Tamm 2014: 91):

(2) a. Finnish

Mari söi omenaa.
Mary eat.PST.3SG apple.PAR.sG
'Mary was eating a/the apple.'
b. Finnish

ilman rahaa
without money.PAR.SG
'without money'
(example from Tamm 2014: 90)

In the tradition of Indo-European scholarship the term 'Partitive' is primarily associated with the genitive (Koptjevskaja-Tamm 2001: 525), although the term also covers phenomena that are not morphological Partitives (for a further discussion see Koptjevskaja-Tamm 2001: 525). In Lithuanian, the 'Partitive' function of the genitive is one among the numerous functions associated with this case ${ }^{2}$; in

\footnotetext{
2 The other functions of the Lithuanian genitive are, for example, genitive proper (e.g. possession brolio.gen kambarys 'brother's room'; origin/material obuolių.GEN sultys 'apple juice').
} 
the domain of object marking it is used mainly to mark part-whole concepts and indefiniteness.

The main goal of this paper is to give an overview of the factors that have been invoked in the literature as affecting the use of the Partitive cases as object cases in Finnish and Lithuanian, and compare their relevance and relative ranking in the two languages. The paper is structured in the following way: Section 1 gives an overview of object marking rules in Finnish and Lithuanian. Section 2 discusses the differential features of partitivity in these two languages. In Section 3, I formulate some generalizations about the hierarchical order of the object-marking rules in each language and about how they relate to each other. Finally, in Section 4, I attempt to formulate prototypical functions for the Partitive in Finnish and the Partitive genitive in Lithuanian.

\section{I.I. OBJECT MARKING IN FINNISH}

In Finnish, the case of the direct object of transitive verbs alternates between the 'total object' (marked with the Accusative) and the 'partial object' (morphologically marked with the Partitive). In this article, the term 'Accusative' will be used as a blanket term for the non-partitive case forms. This case has very little dedicated morphology and is thus largely a non-autonomous case which borrows forms from other cases (on the notion of non-autonomous case, see Blake 2004: 22-24). For singular NPs, the object marker $-n$ is homophonous with the genitive case; ${ }^{3}$ plural direct objects are marked with the nominative plural. A dedicated form (the $-t$ accusative) is used for personal pronouns, for example he 'they.PL.NOM' : heidät 'they.PL.ACC'. The Accusative case is thus defined on the basis of syntactic context, cf. (3):

\footnotetext{
3 Historically, the object-marking genitive was an Accusative with the ending ${ }^{*}-m$, but it coalesced with the original genitive $-n$ after a sound change whereby word-final ${ }^{*}-m$ became -n (Huumo 2013: 91).
} 
(3) Tapasin 'meet.PsT.1SG'

- genitive (ystävän 'friend.ACC.SG = GEN.SG') 'I met a friend';

- nominative ( $y$ stävät 'friend.ACC.PL = NOM.PL') 'I met (my) friends';

- dedicated Accusative (sinut 'you.ACc.sG') 'I met you'.

Finnish object cases are shown in Table 1 below:

Table I. Object cases in Finnish

\begin{tabular}{|c|c|c|c|c|}
\hline & \multicolumn{2}{|c|}{ Singular } & \multicolumn{2}{|c|}{ Plural } \\
\hline & Partitive & Accusative & Partitive & Accusative \\
\hline kala 'fish' & $\begin{array}{l}\text { kala-a } \\
\text { fish-PAR.SG }\end{array}$ & $\begin{array}{l}\text { kala-n (= GEN) } \\
\text { fish-ACC.SG }\end{array}$ & $\begin{array}{l}\text { kalo-j-a } \\
\text { fish-PAR-PL }\end{array}$ & $\begin{array}{l}\text { kala-t (= NOM) } \\
\text { fish-ACC.PL }\end{array}$ \\
\hline avain 'key' & $\begin{array}{l}\text { avain-ta } \\
\text { key-PAR.SG }\end{array}$ & $\begin{array}{l}\text { avaime-n (= GEN) } \\
\text { key-ACC.SG }\end{array}$ & $\begin{array}{l}\text { avaim-i-a } \\
\text { key-PAR-PL }\end{array}$ & $\begin{array}{l}\text { avaime- } t \text { (= NOM) } \\
\text { key-ACC.PL }\end{array}$ \\
\hline karhu 'bear' & $\begin{array}{l}\text { karhu- } a \\
\text { bear-PAR.SG }\end{array}$ & $\begin{array}{l}\text { karhu-n (= GEN) } \\
\text { bear-ACC.SG }\end{array}$ & $\begin{array}{l}\text { karhu-j-a } \\
\text { bear-PAR-PL }\end{array}$ & $\begin{array}{l}\text { karhu- } t(=\text { NOM }) \\
\text { bear-ACC.PL }\end{array}$ \\
\hline hän 'he/she' & $\begin{array}{l}\text { hän-tä } \\
\text { he/she-PAR.SG }\end{array}$ & $\begin{array}{l}\text { häne- } t \\
\text { he/she-ACC.SG }\end{array}$ & $\begin{array}{l}\text { hei-tä } \\
\text { they-PAR }\end{array}$ & $\begin{array}{l}\text { hei-dät } \\
\text { they-ACC }\end{array}$ \\
\hline
\end{tabular}

In Finnish grammar, the Partitive case is described as the default case for the object of a transitive verb; a special feature is required for the assignment of Accusative case (cf. Vainikka 1993, Heinämäki 1984). The Partitive case has three interrelated and often overlapping functions (Vainikka, Maling 1996: 193): quantitative unboundedness of the object referent, which often correlates with an indefinite reading (4), aspectual unboundedness or lack of culmination in the designated event (5), or negation of the propositional content (6):

(4) Löysin marjoja.

find.PST.1SG berry.PAR.PL

'I found [some] berries.'

(5) Kuuntelin radiota.

listen.PST.1SG radio.PAR.sG

'I was listening to a/the radio.' 
(6) En rakentanut taloa.

NEG build.PST.PA house.PAR.SG

'I did not build a/the house.'

'I was not building a/the house.'

Among all these factors, negation is seen as the strongest rule that mandates the use of the Partitive and overrides the other rules (aspect, quantification) in cases where they are in conflict.

The Accusative has a positive meaning, that of total affectedness, which entails quantification, culmination and affirmation, and if these conditions are not met the language resorts to its default case, the Partitive; compare (7a) and (7b):

(7) a. Rakensin talon.
build.PST.1SG house.ACC.SG
'I built a/the house.'
b. Rakensin taloa.
build.PST.1SG house.PAR.SG
$\begin{aligned} & \text { (i) 'I built some of the house.' } \\ & \text { (ii) 'I was building a/the house.' }\end{aligned}$

In (7a) the phrase 'house' designates a discrete entity in its entirety. The object NP is therefore quantitatively bounded (but not necessarily definite), the action has culminated in a result (a/the house was built), and all these factors result in the use of the Accusative.

Historically, the Partitive in Finno-Ugric was a spatial case with separative ("from") meaning (see table 2 below). It is generally assumed that the development of the Partitive goes back to the Volga-Finnic period, when the ablative case was used to express partially affected objects. At a later time, the new composite elative and ablative cases took over the local functions of the original separative case in - $t a$, whose meaning ceased to be spatial and became associated with quantification: 'to eat of/from the bread' came to mean 'to eat some (of the) bread'. In Mordvin, the ablative case occurs on objects of a certain class of verbs similar, but not quite identical, 
to that taking a Partitive object in the Finnic languages (Kiparsky 1998: 32, Koptjevskaja 2001: 534-535). The other original local cases of Proto-Finnic also lost their spatial meanings and acquired grammatical functions: the 'essive' and the 'translative' now mark temporary state and change-of-state respectively. The developments in the Fennic case system are shown in Table 2 below:

Table 2. Local cases in Finnish (Koptjevskaja-Tamm 200I: 534)

\begin{tabular}{|l|l|l|l|}
\cline { 2 - 4 } \multicolumn{1}{c|}{} & \multicolumn{2}{c|}{ Modern Finnish local cases } & \multicolumn{1}{c|}{ Original local cases } \\
\cline { 2 - 5 } \multicolumn{1}{c|}{} & $\begin{array}{c}\text { Inner local case } \\
\text { series }\end{array}$ & $\begin{array}{c}\text { Outer local case } \\
\text { series }\end{array}$ & \multicolumn{1}{c|}{$\begin{array}{c}\text { General local } \\
\text { case series }\end{array}$} \\
\hline static position & Inessive & Adessive & Essive \\
\hline motion towards & Illative & Allative & Translative \\
\hline motion from & Elative & Ablative & Partitive \\
\hline
\end{tabular}

The aspectual object is a feature of Finnic languages, which does not have exact equivalents in other Finno-Ugric languages. Two explanations are given for the aspectual object in Finnish: it could have developed because of the influence of the neighbouring speech communities (Larsson 1984, 2001) or it could have been a development within the Finnic languages themselves. Larjavaara (1991) shows that the object case variation in Finnish has developed in a logical manner and is well motivated throughout on semantic grounds. He argues that quantification is an older criterion than aspect and most probably the starting point from which aspect has developed.

\section{I.2. OBJECT MARKING IN LITHUANIAN}

In Lithuanian, the case of the direct object of transitive verbs alternates between the Accusative and the Partitive genitive. The Lithuanian Partitive genitive is the etymological and functional continuation of the Proto-Indo-European Partitive genitive widely attested across the ancient Indo-European languages (see, inter alia, Seržant 2012, Ambrazas 2006: 216-218): 
(8) a. Jis rado knyg-as.

he find.PST.3 book-ACC.PL

'He found the books.'

b. Jis rado knyg-u.

he find.PST.3 book-GEN.PL

'He found some books.'

As shown by the comparative evidence of the ancient Indo-European languages, the partitive use of the genitive was inherited from Indo-European, but was reinforced by the coalescence of genitive and ablative in Baltic and Slavic (Kurylowicz 1964: 189-190, 1977: 142-143, Ambrazas 2006: 293-294, Seržant 2014: 294).

Lithuanian object cases are show in table 3 below:

Table 3. Lithuanian object cases

\begin{tabular}{|l|l|l|l|l|}
\cline { 2 - 5 } \multicolumn{1}{c|}{} & \multicolumn{2}{c|}{ Singular } & \multicolumn{2}{c|}{ Plural } \\
\cline { 2 - 5 } \multicolumn{1}{c|}{} & $\begin{array}{c}\text { Partitive } \\
\text { genitive }\end{array}$ & Accusative & $\begin{array}{c}\text { Partitive } \\
\text { genitive }\end{array}$ & \multicolumn{1}{c|}{ Accusative } \\
\hline namas 'house' & nam-o & nam-q & nam-ų & nam-us \\
\hline vaisius 'fruit' & vais-iaus & vais-ių & vais-ių & vais-ius \\
\hline dukra 'daughter' & dukr-os & dukr-q̨ & dukr-ų & dukr-as \\
\hline marti 'daughter-in-law' & marč-ios & marč-ią & marč-ių & marč-ias \\
\hline gèlè 'flower' & gèl-ès & gèl-ę & gèl-ių & gèl-es \\
\hline senelis 'grandfather' & senel-io & senel-i & senel-ių & senel-ius \\
\hline pilis 'castle' & pil-ies & pil-i & pil-ių & pil-is \\
\hline dubuo 'bowl' & dub-ens & duben-i & duben- $u$ & duben-is \\
\hline
\end{tabular}

The use of the Lithuanian Partitive genitive differs from that of the Finnish Partitive in many respects. As illustrated by Example (8b) above, the most common use of the Lithuanian genitive is with indefinite non-incremental quantification (where the genitive is used to refer to an indefinite amount or quantity). The use of the Accusative is much more predominant and is to be seen as the default case of the Lithuanian object. Whereas in Finnish it is the Partitive that has a whole array of disparate functions, in Lithuanian this is the case with the Accusative, which is used with incremental 
quantification, when the object participates in the event gradually, and its components are affected in a sequential fashion (9), but also for definite mass nouns (10), and in generic sentences (11):

(9) Ašgeriu kav-ą.

I drink.PRS.1SG coffee-ACC

'I drink coffee.'

(10) Iš-gériau kav-ą.

PVB.drink.PRS.1SG coffee-ACC

'I drank all my coffee.'

(11) Geriu tik kav-a.

drink.PRS.1SG only coffee-ACC

'I drink only coffee.'

However, in line with Finnish (6), in Lithuanian, the direct objects of transitive verbs (even those normally marked with the Accusative) will take the genitive case in negated clauses; this is the so-called genitive of negation, which historically evolved from the Partitive genitive (Ambrazas et al. 1997: 500-506, 667-668):

$\begin{array}{llll}\text { (12) a. } & \text { Brolis nusipirko nauj-a } & \text { nam-a. } \\ \text { brother buy.PST.3 } & \text { new-ACC } & \text { house-ACC } \\ \text { '[My brother bought a new house.' } & \\ \text { b. Brolis ne-nusipirko nauj-o } & \text { nam-o. } \\ \text { brother } & \text { NEG-buy.PST.3 } & \text { new-GEN } & \text { house-GEN } \\ \text { '[My }] \text { brother did not buy a new house.' }\end{array}$

\section{The differential features of partitivity in Finnish and Lithuanian}

As described in Section 1, several factors have been invoked in the literature as affecting the use of the Partitive case in Finnish and the Partitive genitive in Lithuanian. Further below in this paper, their relevance and relative ranking in Finnish and Lithuanian will be discussed in more detail. We will discuss to what extent 
(in)definiteness, partiality and (ir)resultativity are relevant for object marking both in Finnish and Lithuanian.

\section{I. (IN)DEFINITENESS}

Both Lithuanian and Finnish lack a dedicated grammaticalized means to mark the (in)definiteness of an NP. In Lithuanian there is no choice between a house, the house, houses, the houses; tea, the tea. The differences in interpretation are therefore expressed by a variety of morphological, syntactic, prosodic and lexical devices: word order, stress, determiners and quantifiers and various other lexemes that modify nouns (for a detailed study of definiteness in Lithuanian, see Spraunienè 2011).
(13) Pa-stačiau nam-ą. PVB-build.PST.1SG house-ACC 'I built a/the house.'

In (13), nama.Acc 'house' could be interpreted as either definite or indefinite. The determiners tas 'this', anas 'another', vienas 'one' or šitas 'this' modifying nama.ACC would suggest the definiteness of the object:
(14) Pa-stačiau ta nam-a. PVB.build.PsT.1sG this.ACC house-ACC 'I built this house.'

However, certain morphosyntactic features can also enforce a definite interpretation of the noun phrase (a so-called 'definiteness effect'; on this notion see Lyons (1999: 227-252)), e.g. in the case of mass nouns and plurals of count nouns the use of the Accusative for the direct object induces a definite reading, as in (15) for mass nouns and (16) for plurals of count nouns:
(15) Iš-gériau
kav-a, kuri buvo ant stalo. PVB-drink.PST.1SG coffee-ACC which be.PST.3 on table.GEN 'I drank all the coffee that was on the table.' 
(16) Su-valgiau

obuol-ius.

PVB-eat.PST.1SG

apple-ACC.PL

'I ate the apples.'

An indefinite mass noun would have to be marked with the Partitive genitive, as it would naturally be interpreted as an unbounded NP. The Partitive genitive, in combination with the perfective value of the verb, introduces indefinite quantification (see below for further discussion):

(17)
Kavinèje iš-gèriau kav-os.
café.LOC PVB-drink.PST.1SG coffee-GeN
'I went to a café for coffee.'

This means that definiteness, apparently through the bounded reading it imposes, induces the use of the Accusative. However, the genitive (historically also a Partitive genitive) is used for both count nouns and mass nouns if there is negation, which ranks hierarchically higher than definiteness in determining case marking (see section 1.2):

(18) Ne-gèriau kav-os.

NEG-drink.PST.1SG coffee-GEN

'I did not drink coffee.'

(19) Ne-pa-stačiau nam-o. NEG-PVB-build.PST.1SG house-GEN 'I did not build a/the house'

In Finnish, definiteness likewise does not have any dedicated marking. Instead, definiteness effects connected with word order and case in Finnish correspond in irregular ways to the expression of definiteness in English ${ }^{4}$. We could compare below Example (20) from Finnish with Lithuanian Example (15) above, where, in the former,

\footnotetext{
4 Chesterman (1977), among others, suggests that the Finnish case selection, word order, stress, concord and function words such as joku ('some'), eräs ('one'), se ('it'), and tietty ('certain') express different aspects of the English article system. Chestermann states that in
} 
the object is a count noun and refers to a bounded entity (hence a closed quantity), so that in this case the use of the Accusative does not automatically induce a definite reading:

(20) Kirjoitin kirjeen, jonka lähetin ystävälle. write.PST.1SG letter.ACC which.GEN send.PST.1SG friend.ALL 'I wrote a/the letter, which I sent to a friend.'

Since definiteness is only a default reading that typically correlates with boundedness of the quantity expressed by the Accusative object, (in)definiteness cannot be associated directly with the function of the PAR/ACC cases as regards mass nouns (21) (the same applies for plurals). In Example (21a), the Accusative veden 'water' conveys that the quantity is bounded, and (most likely) that the object NP is definite ('the water'), but definiteness is only a default reading. An indefinite reading is possible if the object, for example, refers to a serving of water, as in a café ('Jukka ordered a water'). In Example (21c), an indefinite reading is excluded by the relative clause that modifies the object NP (in fact, it is the relative clause that triggers the definite reading in (21c):

(21) a. Jukka joi veden.

Jukka drink.PST.3SG water.ACC

'Jukka drank a water / all his water.'

b. Jukka tilasi veden.

Jukka order.PST.3Sg water.ACC

'Jukka ordered a water.'

c. Jukka joi veden, joka oli pöydällä.

Jukka drink.PST.3SG water.ACC which be.PST.3SG table.ADE 'Jukka drank all of the water that was on the table.'

The Partitive genitive in Lithuanian operates on NPs that are by themselves unbounded. In addition to Example (17) above, I give examples of a mass noun with an indefinite and non-specified

Finnish, function words such as those listed above are used to mark identifiability, i.e. the known/unknown status of a referent. 
quantity reading (22) (the same applies to plurals). The NP vanduo 'water' is in itself unbounded, but the perfective aspect of the verb requires boundedness, which is introduced by the genitive. Without a case ending the nominal would be merely a stem (of a mass noun), expressing a type of a referent (a mass). Actual quantification (bounded or unbounded) is then expressed by the case:

(22) Pa-gériau

PVB-drink.PST.1SG

'I drank (some) water.' vand-ens.

water-GEN

The indefinite quantification of the object may correlate with the use of verbal prefixes such as: pri-, meaning 'a lot, enough', per- meaning 'a lot, too much', as well as $u \check{z}$ - 'a little bit', also in combination with the reflexive marker -si- (už-si-kasti duonos 'to eat a little bit of bread', per-si-valgyti obuoliu 'to eat too many apples'; for more detail see Ambrazas et al. (2006: 503)) With verbs containing these prefixes the object NP must be indefinite and the use of the Accusative is impossible:

(23) At-si-geriau/ pri-si-gériau kav-os PVB-RFL-drink.PST.1SG/ PVB-RFL-drink.PST.1SG coffee-GEN.SG $\left({ }^{*} k a v-a\right)$.

( ${ }^{*}$ coffee-ACC)

'I drank some coffee./ I drank my fill of coffee.'

With the Lithuanian quantifying verb prefixes an NP-related meaning (quantification) is expressed in the verb structure while Finnish in turn expresses a verb-related meaning, i.e., aspect, by the case of the object.

Finnish Example (24) shows that a Partitive object is able to indicate indefinite quantity ('a certain quantity of water'), but only in aspectually bounded situations:
Lapset
joivat
vettä.
child.NOM.PL
drink.PST.3PL
water.PAR
'The children drank some (of the) water'. 
This sentence also has an imperfective, i.e. aspectually unbounded, reading: 'The children were drinking (the) water':

(25) Lapset joivat vettä, kun puhelin soi. child.NOM.PL drink.PST.3PL water.PAR when phone.NOM ring.PST.3SG 'The children were drinking (the) water, when the phone rang.'

The influence of aspect on object marking will be discussed in detail below, but the compatibility with verbs receiving an imperfective reading suggests that the Partitive case is not in itself bounded.

\subsection{PARTIALITY}

The notion of 'partitivity' has been used in different ways in the literature. 'Partitive' has to do with reference to subsets of definite (super)sets ( $\mathrm{N}$-of-the- $\mathrm{N}$, example (1b)), indication of the quantity, which is singled out by a nominal quantifier (N-of-N, example (1a)), also with reference to indefinite quantity or 'partial objects' of certain verbs (for a more detailed list see Koptjevskaja-Tamm (2001: 525-526) and the literature mentioned therein). One of the meanings of 'partitivity' is indefinite quantification, already discussed in Section 2.1. Note that Finnish Example (26) indicates indefiniteness and does not refer to a part of a previously identified whole:

(26) Opettaja osti kirjoja.

Teacher buy.PST.3SG book.PAR.PL

'The teacher bought some (indefinite quantity and not previously identified) books.'

Another meaning of partitivity, which, for greater clarity, we will henceforth refer to as partiality, is to be seen in cases where part of a discrete object or a larger reference mass is affected by an action, as in 'to eat of/from the bread', or 'to drink from the water'. It is only in cases like these that we can speak of a part-to-whole relationship:

(27) Lapsi söi child.NOM eat.PST.3SG viipaleen leipääl leivän. 'The child ate a slice of bread/ the bread. 
The above example contains a verb of consumption. The use of the Accusative in the case of leivän indicates that the child consumed all of the bread given to them, while the combination of Accusative and Partitive in viipaleen leipää is used to indicate that only a separate and well-defined portion of the whole (e.g. the slice of bread) was consumed while the rest of the bread still remains. The affected part has been thoroughly affected: the given piece of bread has been fully consumed, but the difference from total affectedness follows from the fact that the whole entity was not targeted and the rest remains unaffected (Luraghi, Kittilä 2014: 41).

In Finnish, there is a series of measure nouns (such as lasi 'glass', kori 'basket', pullo 'bottle') governing Partitives. This is a function related to the use of the Partitive with many kinds of quantifying expressions to indicate the quantified mass (kaksi poikaa.PAR 'two boys'). In Lithuanian, NPs designating quantification, appear with the genitive (maišas miltų.GEN.PL 'a sack of flour').

\subsection{INCREMENTAL QUANTIFICATION}

Partiality (or partial affectedness) can also be seen in events involving an incremental ${ }^{5}$ participant. In such events the referent of the object participates in the event gradually, and its components are affected in a sequence. The quantity indicated by an NP is affected by clausal aspect if the referent of the NP participates in the event incrementally:

(28) Kirjoitin

kirjettä.

write.PST.1SG letter.PAR

'I was writing a/the letter.'

In this above Finnish example, PAR can indicate a progressive meaning, where the event is ongoing - 'I was writing a letter (at that

\footnotetext{
5 Dowty defines the incremental theme as a distinct semantic role. The incremental theme can be a patient or a result: (build a house, write a letter, perform a sonata, eat a sandwich, paint a house, polish a shoe, proofread an article (Dowty 1991: 568)).
} 
particular moment)', or it can indicate a cessative meaning, where the event is terminated before it reaches its potential end point 'I wrote a part of the letter', 'I've been working on that letter'. In order to disambiguate the sentence, a wider context is needed, as in Example (29):

$\begin{array}{llll}\text { (29) Kirjoitin kirjettä, } & \text { kun puhelin soi. } \\ \text { write.PST.1SG } & \text { letter.PAR when phone.NOM } & \text { ring.PST.3SG } \\ \text { 'I was writing a/the letter when the phone rang.' }\end{array}$

Since the object NP is incremental in (29), this determines a certain type of quantification of the object, which can be relevant for case marking ${ }^{6}$ the writing of the letter has proceeded to cover the letter partially, but not completely. A count noun ('a/the letter') referring to a bounded entity, is accessible to quantification because of the incremental participation in the event as the activity proceeds along the letter gradually and reaches its endpoint when the whole letter has been written (Huumo 2013: 93). The quantity of the letter sets certain boundaries to the duration of the process as the writing of the letter cannot take any longer than the time needed to write the letter. ${ }^{7}$

In such a sentence, the Accusative indicates the combination of bounded aspect and closed quantity (Example (20)). The event thus reaches the endpoint (the potential continuation of the event is excluded as the event has been brought to its endpoint) and the closed quantity is affected in full. Once the whole letter is ready, the total event of 'writing the letter' is over, which is grammatically marked with the Accusative.

The quantifying function of the Accusative is seen in sentences that indicate an achievement (20). Such events are indisputably

\footnotetext{
6 For analogies between the aspectual (verbal) and quantificational (nominal) domains and how clause-level aspect depends on the contribution of many clausal elements, not just the verb, see Huumo (2010:2) and the literature mentioned therein.

7 Huumo (2010) refers to such dependence of clausal aspect on nominal quantity to as nominal aspect.
} 
bounded, which excludes the use of the Partitive as in (29). Since achievements (e.g., löytää 'find', huomata 'notice') are strictly punctual and indicate events that culminate instantly, the Partitive cannot be used for its aspectual function where it indicates non-culmination (for example, a progressive meaning).

However, slightly different criteria for determining the object case apply in Finnish for iterative situations. The case of the object is determined by the nature of the component situations, even though there may be other aspectual elements present (e.g. durative modifiers) that relate to the event at the more abstract level of the habitual state. If the component situations fulfill the criteria for using ACC, then ACC is used even though the overall situation is unbounded. The aspectual unboundedness of the overall habitual situation is shown by the fact that a direct durative modifier (vuoden ajan 'for a year') can be used in spite of the presence of the Accusative, which is otherwise incompatible with the unboundedness of the situation (Huumo 2010: 101-105). It is widely attested in different languages that durative modifiers are only compatible with clauses that refer to unbounded situations and not with bounded situations (Huumo (2013: 105) and the literature mentioned therein). In Finnish, the durative modifiers are marked with the same case as the (total) object (30a). The duration of the bounded situation is indicated by adverbials, which set a certain time-span within which the event is completed (30b). In Finnish, time-span adverbials take the inessive case (Huumo 2010: 90, 2013: 105):

(30) a. Olen lukenut lehden kirjastossa
be.PRS.1SG read.PST.PA paper.ACC library.INEss
jo vuoden ajan. ${ }^{8}$
already year.GEN time.ACC
'For a year already, I have been reading the newspaper in the
library.'

8 Example taken from Huumo (2010: 101). 


\section{b. Luin lehden tunnissa. \\ read.PST.1SG paper.ACC hour.INESS \\ 'I read a/the newspaper in an hour.'}

The conceived boundedness of the higher-level habitual situation follows from the presence of the durative modifier, not from the boundedness of the component events (30a). At the habitual level, the situation is static and thus unbounded: the person has the habit of reading the paper in the library. As such, the habitual situation is unbounded (because the bounded component event can be repeated innumerable times). The durative modifier indicates that the habit of reading the paper in the library has lasted for a year. Boundedness is indicated at two different levels: Accusative indicates the boundedness of each component situation (i.e. the reading of the whole paper), whereas the durative modifier sets temporal boundaries to the overall habitual state (Huumo 2010: 101).

As shown above, in Finnish, the aspect is encoded in the case marking of the object: the Accusative indicates the bounded aspect as in (20), while the Partitive with count nouns refers to incremental participation in the event as in (29). In Lithuanian, the difference in aspect is marked in imperfective/perfective verbs as in examples (31) and (32) $)^{9}$. Incremental quantification is not distinguished from holistic quantification in Lithuanian, which is perhaps associated with the inherently unbounded character of incremental quantification:
(31) Pa-rašiau laišk-ą.
PVB-write.PST.1SG letter-ACC
'I wrote a/the letter.'
(32) Rašiau laišk-ą.
write.PST.1SG letter-ACC
'I was writing a/the letter.'

9 For more detail, see Holvoet, Čižik (2004: 142-145). 
As pointed out in Section 1.1 on object marking in Finnish, the Partitive case has three interrelated and often overlapping functions: negation, unbounded aspect, and quantification, whereby negation is the strongest criterion and quantification is the least important criterion for Partitive object. ACC can only be used if the sentence does not meet any criterion of the Partitive (for some exceptions see the discussion below) as in (21). With mass nouns, the basic functions of the Partitive object apply: it expresses either non-culminating aspect or unbounded quantity (or both together). Example (33) illustrates this:
(33) Join kahvi-a. drink.PST.1SG coffee-PAR.SG
(i) 'I was drinking (the) coffee.'
(ii) 'I drank some (of the) coffee.'

With the progressive reading, the example does not tell us whether the projected endpoint of the event would involve a closed or an open quantity of the coffee (the opposition between 'I was drinking coffee' and 'I was drinking the coffee'). With the cessative interpretation, as well, the example does not tell us whether the event had been proceeding towards an endpoint involving a closed quantity ('I drank some of the coffee') or not ('I drank some coffee'). Therefore, (21) shows that the Accusative is used only if the situation has both reached its endpoint and has affected a closed quantity ('Jukka drank all the water that was on the table'). The Finnish Partitive is of a multifunctional nature, and when indicating a more dominant function (incremental theme) the Partitive conceals less dominant features, which it can encode in other contexts (e.g., quantity) (Huumo 2010: 91).

In Lithuanian, examples for the influence of aspect on the semantic properties of nominal arguments are found in sentences that contain mass NPs without a determiner (such as a demonstrative): 
(34) Geriau vanden- $i$.

drink.PST.1SG water-ACC

'I drank (the/some) water.'
(35) Iš-gèriau vanden-ị.
PVB.drink.PRS.1SG water-ACC
'I drank all the water.'

Examples (34) and (35) contain the same mass noun vanduo 'water'. Formally, these two sentences only differ in aspect, marked on their main verbs. But this aspectual difference entails a difference in the interpretation of their direct object NPs. Example (35) contains the prefixed perfective verb $i \check{\text { š }}$-geriau and entails that the event ended when the agent finished drinking all the water. Moreover, the speaker presupposes that the hearer can identify the relevant portion of water in the discourse. Nevertheless, the imperfective verb geriau could also be used with the Partitive genitive as in (36):
(36) Jie sugrižo, valgé duonos ir gère
they come.PST.3. drink.PST.3. bread.GEN and drink.PST.3 vandens [jo namuose]. ${ }^{10}$ water.Gen [in his house] 'They came back, ate (the) bread and drank (the) water at his house.'
*'They came back, were eating (the) bread and drinking (the) water at his house.'

This example suggests that there was a bounded amount of water which the person drank. Unlike in the case of (35), where the perfective verb introduces boundedness, no boundedness is entailed by the imperfective verb in (36). We assume therefore that the genitive marking imposes boundedness on a NP with imperfective verbs. It should be pointed out that (36) cannot have a progressive (and incremental) reading ('they were eating (the) bread and drinking (the)

10 Example taken from http://www.charity.lt/biblija/index.php?s=1\%20Kar\%2013,19 
water'), otherwise the Accusative would have to be used. It is not clear how the imperfective verb geré 'drank' in (36) differs from the perfective pa-gerti 'drink a little bit, have a sip' as in (22); this seems to be an instance of the so-called 'factual' use of the imperfective past, which is well known from Russian (cf. Groenn 2003) and is also possible in Lithuanian, though it has never been described for this language. The factual imperfective is a use of the imperfective that functions on the territory of the perfective (which, in turn, is associated with complete events). The differences between factual uses of imperfective past, imperfective and perfective readings are illustrated by Lithuanian examples (37a) and (37b):

(37) a. Jonas skaite 'Hamleta'.

(i) Jonas was reading 'Hamlet'. (processual imperfective reading)

(ii) Jonas has read 'Hamlet'. (factual imperfective reading)

b. Jonas per-skaitè 'Hamleta'.

'Jonas (has) read 'Hamlet'. (perfective reading)

Factual imperfective and perfective readings both refer to complete events of reading 'War and Peace'. A factual imperfective reading can either assert or presuppose the existence of an event of the verbal predicate (Groenn 2003: 11).

\subsubsection{GENERIC USES}

Differences between the two languages appear also in the marking of the object in generic statements. Generic use is ungrammatical with the genitive in Lithuanian in case of mass nouns, even though the verb gerti 'to drink' combines with the genitive elsewhere, for example for indefinite quantification (Pageriau vandens.GEN 'I drank (some) water'):

$\begin{array}{llll}\text { (38) Visada } & \text { geriu } & \text { arbat- } a & \left({ }^{*} \text { arbat-os }\right) . \\ \text { always } & \text { drink.PRS.1SG } & \text { tea-ACC.SG } & \left({ }^{*} \text { tea-GEN.SG }\right) \\ \text { 'I always drink tea.' } & & \end{array}$


The same applies to plural discrete objects: even though genitive is possible for indefinite quantification (as in Nupirkau geliu.GEN 'I bought some flowers'), only the Accusative is possible with generic use:
(39) Valgau tik obuolius.
eat.PRS.1SG only apple.ACC.PL
'I eat only apples.'

In Finnish generic sentences, the Partitive is used both with mass nouns (40) and plural discrete objects (41).
(40) a. Juon
aina tee-tä.
drink.PRS.1SG always tea-PAR
'I always drink tea.'
b. Juon aina tee-n.
drink.PRS.1SG always tea-ACC
'I always have a tea.'
(41) a.Syön vain omenoita.
eat.PRS.1SG only apple.PAR.PL
'I eat only apples.'
b.Syön vain omenat.
eat.PRS.1SG only apple.ACC.PL
'I eat only the apples.'

However, the Accusative is acceptable in generic sentences if the type of situation of which the generic generalization is made is of a bounded type in terms of aspect and quantification. Sentence (40b) is grammatically correct if the quantity of the tea is bounded in the situation type that underlies the generic expression; i.e., if the speaker always has a (serving of) tea when he/she goes to the café ('I always have a tea'). Even in (41b), 'I only eat the apples', the Accusative object is possible in a generic context where, for example, the speaker's grandmother always brings him apples and bananas when she visits, but he only eats the apples (brought). Thus, genericity as such does not prohibit the use of the Accusative, though it is 
certainly true that the Partitive is the default case for the object in such examples.

Such examples also show that in Finnish, generic statements culmination is possible in cases when the generic predication concerns a culminating situation type (and therefore the Accusative object can be used). In fact, the earlier example (30) is evidence of this (assuming that habitual sentences are classified as generic).

\section{3. (IR)RESULTATIVITY}

In addition to (in)definiteness and partiality functions, there is another function for the Finnish Partitive referred to as (ir)resultativity. The resultative situation indicates a transition: the event brings about a change, after which it does not return to its original state but enters another one. The irresultative situation indicates that no such transition takes place and after completion of the event the situation returns to the original state or to a state that is conceptualized as similar to the original state. Such distinctions are also reflected in the opposition between the Finnish object markers.

The general rule of using the Partitive object for non-culminating aspect types (i.e., the aspectual Partitive) apply for all verbs discussed under this section of irresultativity. However, the oppositions between resultativity and irresultativity cover different subtypes of non-culminating aspect, which will be discussed below in more detail.

A certain group of verbs are inherently atelic (or, according to Vendlerian classification, denoting a state), and take the Partitive case for their objects, as the action never reaches an endpoint. These verbs are instances of unbounded, non-culminating aspect and the use of the Partitive thus follows from their aspectual nature. Kiparsky (1998: 15) gives lists of atelic verbs that assign Partitive case to all their objects as per general aspectual object-marking rule. Such verbs usually denote psychological and emotional states or attitudes, cognition or experience (e.g. rakastaa 'love', inhota 'hate', ihailla 
'admire', kadehtia 'envy', kunnioittaa 'honor', väsyttää 'tire', ajatella 'think', etc.) $)^{11}$ :
(42) Jukka
rakastaa
Anna-a.
Jukka love.PRS.3SG
Anna-PAR
'Jukka loves Anna.'

On the basis of the resultativity vs. irresultativity opposition, Finnish punctual verbs can be divided into two groups: resultative (accomplishment / achievement) verbs such as tappaa 'kill', ostaa 'buy', huomata 'notice' and löytää 'find' that take the aspectual Accusative object, and irresultative (semelfactive) verbs such as tönäistä 'nudge', mulkaista 'glance' and lyödä 'hit' that take the aspectual PAR object (Huumo 2010: 92). For semelfactive verbs, the situation ends in time but fails to bring about a culmination (a fundamental change in the object referent) to trigger the Accusative. Some achievement verbs, such as ampua 'shoot', allows both a resultative and an irresultative reading, which is then reflected in the case marking of its object. The aspectual nature of the verb ampua 'shoot' and the aspectual oppositions expressed by the case of the object have been discussed at length by many authors (for example, Heinämäki (1984: 153), Kiparsky (1998: 2-3)). It is stated that the resultative (43a) versus irresultative oppositions (43b) indicate either the achievement or a lack of a result:
a. Metsästäjä ampui linnu-n.
Hunter.NOM shoot.PST.3Sg bird-ACC
'The hunter shot (down) the bird.'
b. Metsästäjä ampui lintu-a.
Hunter.NOM shoot.PST.3Sg bird-PAR
'The hunter shot at a/the bird (the bird did not die).'

Irresultative marking also applies to situations where the original state is almost the same as the target state; therefore there is no distinction between the two:

\footnotetext{
11 For the full lists of verbs indicating which case they usually take, see Denison 1957: 143-159, Vainikka 1989: 322-324, Kiparsky 1998.
} 


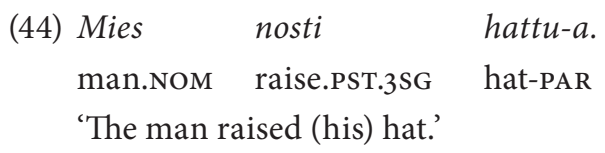

In (44) the man raises his hat for a moment and puts it back: the target state does not significantly differ from the original state. The sentence Mies nosti hatun.ACC päästään 'the man took off his hat' would indicate a transition from one state to another (Leino 1991: 171-172).

Some Finnish verbs allow two readings differing in the temporal stability of the resultant state. One such verb would be lainata 'borrow, lend'. Depending on the speaker's implications, both PAR and ACC are possible. In (45a) the girl is expecting to get her watch back in a while, whereas in (45b) the event of lending the watch is completed in the sense that there are no expectations as to whether and when she will receive the watch back:

$\begin{array}{rlll}\text { (45) a. } & \text { Tyttö } & \text { lainasi } & \text { kello-a. } \\ & \text { girl.NOM } & \text { lend.Pst.3sG } & \text { watch-PAR } \\ \text { b. } & \text { Tyttö } & \text { lainasi } & \text { kello- } n . \\ & \text { girl.NOM } & \text { lend.Pst.3sG } & \text { watch-ACC } \\ & \text { 'The girl lent [her] watch [to somebody].' }\end{array}$

Irresultative use of genitive is very rare in Lithuanian. In Eastern Lithuanian dialects, the genitive may be used instead of the Accusative for the object of verbs of transfer in order to encode that the result of transfer is to be temporally delimited (Seržant 2014: 286). The Partitive genitive in (46a) has the implication of temporariness of the results of the transfer; the Accusative object in (46b) has no such implication. The use of the genitive in (46a) relates to the short time the knife is needed.

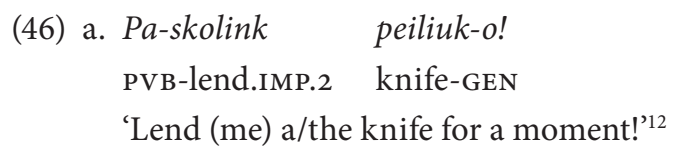

12 Example taken from Ambrazas et al. (1976: 25). 
b. Duok peiliuk-a!

give.IMP.2 knife-ACC

'Give (me) a/the knife!'

\section{Discussion}

In this article, object marking in Finnish and Lithuanian was compared. The hierarchies of the object-marking rules are represented in Figures 1 and 2 below. For Finnish (Figure 1), the strongest rule for using the Partitive is any kind of negation of propositional content. The second condition for the choice between the Partitive and the Accusative is the aspect. Any kind of non-culmination of the event results in the Partitive. This rule applies also for atelic verbs (as state verbs like love or hate do not denote a culmination of the event/point) and incremental themes (as with the progressive reading I am writing a/the letter the event is ongoing and just reaching the culmination point). Irresultativity discussed in Section 2.3 results in Partitive: there is no significant difference between the target state and original state and no culmination point of the event (He shot at a/the bird). The least important condition for the choice between Partitive and Accusative is the quantification of the object: Accusative emerges only when the closed quantity is affected in full (I wrote a/the letter).

For Lithuanian (Figure 2 below), the strongest condition for using Partitive genitive is negation (like for Finnish). The second condition to be taken into account is the incremental participation in the event. With incremental quantification, the default case of the Lithuanian object (Accusative) is triggered (I was writing a/ the letter). Indefinite quantification of the object results in the Partitive genitive (I drank some water). Non-incremental bounded events are marked with the default case of the object - the Accusative (I wrote a/the letter). Some exceptions are made only for time-restricted irresultative events (Lend me a/the knife for a moment!), but such use of the Partitive genitive in Lithuanian is not common. 
(PAR/ACC)
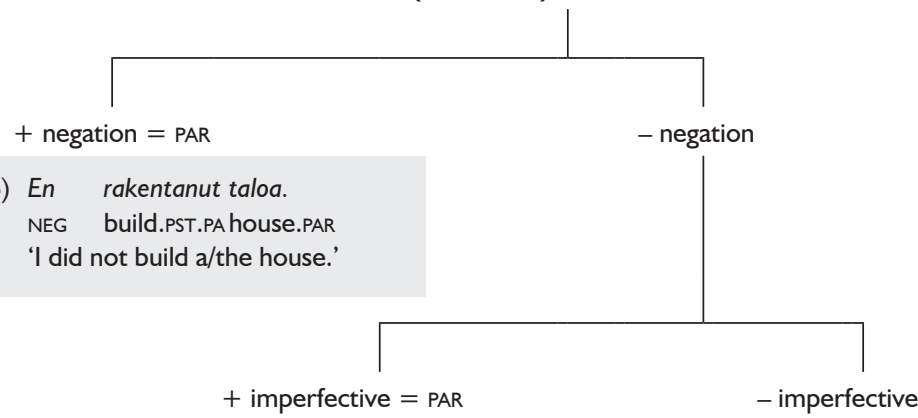

(25) Lapset joivat vettä, kun puhelin soi.

child.NOM.PL drink.PST.3PL water.PAR when phone.NOM ring.PST.3sG

'The children were drinking (the) water, when the phone rang.'

(29) Kirjoitin kirjettä, kun puhelin soi.

write.PST.ISG letter.PAR when phone.NOM ring.PST.3SG

'I was writing a/the letter, when the phone rang.'

(42) Jukka rakastaa Annaa.

Jukka love.PRS.3sg Anna.PAR

'Jukka loves Anna.'

(43b) Metsästäjä ampui lintua.

Hunter.NOM shoot.PST.3sG. bird.PAR

'The hunter shot at a/the bird.'

bounding quantifying (unbounded) = PAR

bounded $=$ ACC
(24) Lapset
joivat
vettä.
child.NOM.PL drink.PST.3PL water.PAR
'The children drank some (of the water'.
(20) Kirjoitin kirjeen.
write.PST.ISG. letter.ACC
'I wrote a/the letter.'

(2la) Jukka joi veden.

Jukka drink.PST.3sG water.ACC 'Jukka drank up the water.'

Figure I. Finnish object cases 


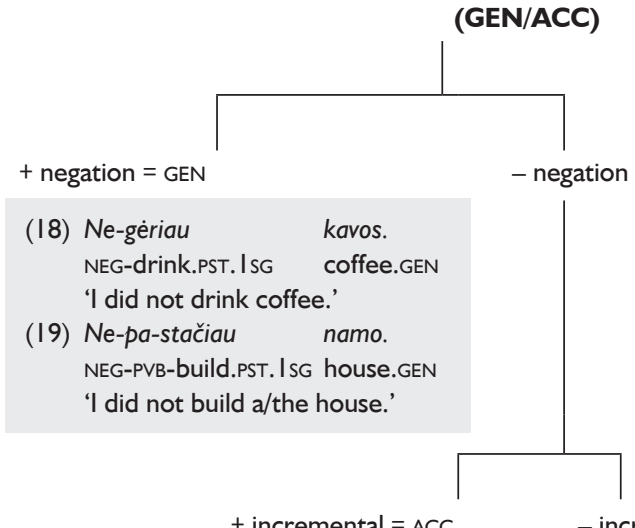
(32) Rašiau laišką. write.PST. ISG. letter.ACC 'I was writing a/the letter.'
(34) Gèriau vandeni. drink.PST.ISG water.ACC 'I drank (the/some) water.'

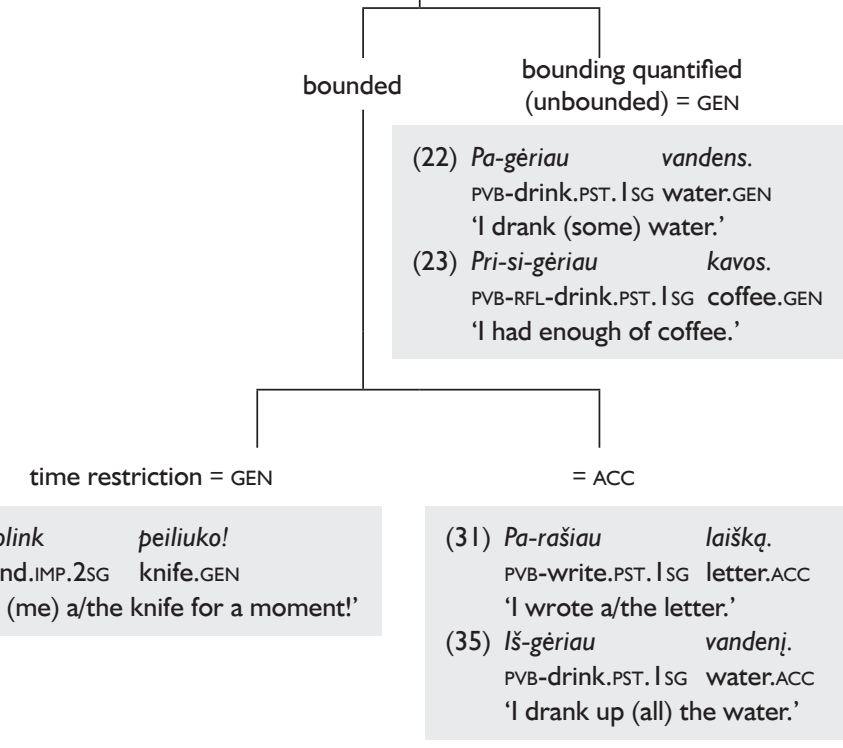

Figure 2. Lithuanian object cases 
Some functions of the Finnish Partitive and Lithuanian Partitive genitive in object marking are identical, but some are very different:

- In the context of negation, both Lithuanian and Finnish have Partitive or Partitive genitive case marking;

- Partiality, a situation where a part of a discrete object or a larger reference mass is affected by an action ('to eat of/from the bread' or 'to write a part of the letter') is a feature of Finnish, but not Lithuanian;

- Incremental participation in the event is relevant for case marking only in Finnish: since the object NP is incremental, it is exposed to quantification and marked with the Partitive. In Lithuanian, the distinction between incremental and non-incremental quantification is conveyed by oppositions between perfective and imperfective verbs.

\section{Conclusions}

Lithuanian and Finnish have completely different prototypes for assigning object cases. In Finnish the prototype is culmination (or the absence of culmination); in Lithuanian the prototype is quantification. In Finnish grammar, the Partitive case is described as the default case for the object of a transitive verb. In Lithuanian, the Accusative is the default case of the Lithuanian object. The point of departure for the development of the object cases in the two languages was most probably the same at the beginning (indefinite quantification of the object referent), but Finnic and Baltic languages developed in two different directions. The differences could have arisen because of the different developments of the aspectual systems in the two languages. Lithuanian object marking seems to be closer to the original object marking system as we can reconstruct it for both languages. To conclude, Partitive or Partitive genitive plays different roles for Finnish and Lithuanian. 


\begin{tabular}{|c|c|c|c|}
\hline \multicolumn{4}{|c|}{ ABBREVIATIONS } \\
\hline $1,2,3$ & first, second, third person & NOM & nominative \\
\hline ACC & accusative & PA & active participle \\
\hline ALL & allative & PL & plural \\
\hline ELA & elative & Poss & possessive \\
\hline ESS & essive & PP & passive participle \\
\hline gen & genitive/partitive genitive & PRS & present \\
\hline ILL & illative & PAR & partitive \\
\hline IMP & imperative & PST & past \\
\hline INE & inessive & RFL & reflexive \\
\hline INF & infinitive & PVB & preverb \\
\hline LOC & locative & SG & singular \\
\hline NEG & negation & SUP & superlative \\
\hline
\end{tabular}

\section{REFERENCES}

Ambrazas, Vytautas; Dumašiūtè, Zelma; Juodelytė D.; Kniūkšta, Pranas; Labutis, Vitas 1976. Lietuvių kalbos gramatika. III tomas. Sintaksẻ [Lithuanian grammar. Syntax]. Vilnius: Mokslas.

Ambrazas, Vytautas. 2006. Lietuvių kalbos istorinè sintaksė [Historical syntax of the Lithuanian language]. Vilnius: Lietuvių kalbos institutas.

Ambrazas, Vytautas; Garšva, Kazimieras; Girdenis, Aleksas; Jakaitienè, Evalda; Kniūkšta, Pranas; Krinickaitè, Stasè; Labutis, Vitas; Laigonaitè, Adelè 2006. Dabartinès lietuvių kalbos gramatika [A Grammar of Modern Lithuanian]. Vilnius: Lietuvių kalbos institutas.

Blake, Barry J. 2004. Case. 2nd edition. Cambridge: Cambridge University Press.

Chestermann, Andrew 1977. Definiteness in Finnish. - Papers and Studies in Contrastive Linguistics 7, 111-120.

Denison, Norman 1957. The partitive in Finnish. Helsinki: Suomalainen Tiedeakatemia.

Groenn, Alte 2003. The Semantics and Pragmatics of the Russian Factual Imperfective. Oslo: University of Oslo (Doctoral Dissertation).

Heinämäki, Orvokki 1984. Aspect in Finnishh. - Aspect bound: A voyage into the realm of Germanic, Slavonic and Finno-Ugrian aspectology. Eds. Casper de Groot, Hannu Tommola. Dordrecht: Foris Publications, 153-177. 
Holvoet, Axel; Čižik, Veslava 2004. Veikslo priešpriešos tipai [Types of aspectual opposition]. - Gramatinių kategorijų tyrimai [Studies in grammatical categories]. Eds. Axel Holvoet, Loreta Semėnienè. 141-162.

Huumo, Tuomas 2010. Nominal aspect, quantity, and time: The case of the Finnish object. - Journal of Linguistics 46, 83-127.

Huumo, Tuomas 2013. On the many faces of incompleteness: Hide-and-seek with the Finnish partitive object. - Folia Linguistica 47/1, 89-111.

Kiparsky, Paul 1998. Partitive Case and Aspect. - Projecting from the Lexicon. Eds. Miriam Butt, Wilhelm Geuder. Projecting from the Lexicon, Stanford: CSLI, 1-38.

Klaas, Birute 1996. Similarities in case marking of syntactic relations in Estonian and Lithuanian. - Estonian Typological Studies I. Ed. Mati Erelt. Publications of the Department of Estonian of the University of Tartu 4, 37-67.

Koptjevskaja-Tamm, Maria 2001. "A piece of the cake" and "A cup of tea": partitive and pseudo-partitive nominal constructions in the CircumBaltic languages. - The Circum-Baltic Languages: Typology and Contact, vol 2. Eds. Östen Dahl, Maria Kopjevskaja-Tamm. Amsterdam: Benjamins, 523-568.

Koptjevskaja-Tamm; Wälchli, Bernhard 2001: The Circum-Baltic languages. An areal-typological approach. - The Circum-Baltic Languages: Typology and Contact, vol. 2. Eds. Östen Dahl, Maria Kopjevskaja-Tamm. Amsterdam: Benjamins, 615-750.

Kuryłowicz, Jerzy 1964. The Inflectional Categories of Indo-European. Heidelberg: Carl Winter Universitätsverlag.

Laakso, Johanna 2001. The Finnic languages. - The Circum-Baltic Languages: Past and Present, vol 1. Eds. Östen Dahl, Maria KopjevskajaTamm. 179-212.

Larjavaara, Matti 1991. Aspektuaalisen objektin synty [The origin of the aspectual object]. - Virittäjä 95, 372-408.

Larsson, Lars-Gunnar 1984. The role of Baltic influence in the aspectual system of Finnish. - Aspect bound. Eds. Casper de Groot, Hannu Tommola. Dordrecht: Foris Publications, 97-109.

Larsson, Lars-Gunnar 2001. Baltic influence on Finnic languages. - The Circum-Baltic Languages. Typology and Contact. Eds. Östen Dahl, 
Maria Koptjevskaja-Tamm. Amsterdam: John Benjamins. SLCS Vol. 54, 237-256.

Leino, Pentti 1991. Lauseet ja tilanteet. Suomen objektin ongelmia [Clauses and situations: Problems in object marking in Finnish], Suomi 160, Helsinki: Suomalaisen Kirjallisuuden Seura.

Luraghi, Silvia; Kittilä, Seppo 2014. Typology and diachrony of partitive case markers. - Partitive Cases and Related Categories. Eds. Silvia Luraghi, Tuomas Huumo. Berlin: Mouton-De Gruyter, 17-62.

Lyons, Christopher 1999. Definiteness. Cambridge: Cambridge University Press.

Seržant, Ilja 2012. Pragmatics and semantics of the bare partitive genitive in Ancient Greek. - Sprachtypologie und Universalienforschung 65, 2, 113-136.

Seržant, Ilja 2014. The independent partitive genitive in Lithuanian. - Grammatical Relations and their Non-Canonical Encoding in Baltic. Eds. Axel Holvoet, Nicole Nau. Amsterdam-Philadelphia: John Benjamins, 257-299.

Spraunienè, Birutė 2011. Apibrèžtumo žymèjimas lietuvių kalboje lyginant su danų ir kitomis artikelinèmis kalbomis [The marking of definiteness in Lithuanian. Against the background of Danish and other article languages], daktaro disertacija. Vilniaus universitetas.

Tamm, Anne 2014. The Partitive Concept versus Linguistic Partitives: From Abstract Concepts to Evidentiality in the Uralic Languages. - Partitive cases and related categories. Eds. Silvia Luraghi, Tuomas Huumo. Berlin: Mouton-De Gruyter, 89-151.

Vainikka, Anne 1993. Three structural cases in Finnish. - Case and Other Functional Categories in Finnish Syntax. Ed. Nikanne Urpo Anders. Berlin: Mouton-De Gruyter, 129-160.

Vainikka, Anne; Maling, Joan 1996. Is partitive case inherent or structural? - Partitives: Studies on the Syntax and Semantics of Partitive and Related Constructions. Ed. Jacob Hoeksema. Berlin: Mouton-De Gruyter, 179-208. 


\section{PARTITIIVSUS JA OBJEKTI MARKEERIMINE SOOME JA LEEDU KEELES}

Nii soome kui ka leedu keeles võib objekti markeerimisel rääkida partitiivsusest.

Soome keeles võib transitiivse verbi objekt olla akusatiivis või partitiivis, kusjuures partitiiv on kõige tavalisem objekti kääne ning akusatiivi kasutuse tingivad teatud tegurid. Leedu keeles võib transitiivse verbi object olla kas akusatiivis või partitiivi genitiivis.

Vastavused leedu partitiivse genitiivi ja soome partitiivi vahel katavad laia semantilis-süntaktilist ala. Mõned funktsioonid on mõlemas keeles identsed, mõned on erinevad. Leedu keeles on genitiivi partitiivne funktsioon üks arvukatest selle käände funktsioonidest; objekti markeerimise puhul kasutatakse partitiivi väljendamaks osa-terviku suhet ja indefiniitsust. Soome partitiivil on kolm osati kattuvat funktsiooni. Artikkel annab ülevaate partitiivi eri funktsioonide sagedusest ning formuleerib soome partitiivi ja leedu genitiivi prototüüpsed funktsioonid.

Võtmesõnad: partitiivsus, objekti markeerimine, partitiiv, genitiiv, akusatiiv, soome keel, leedu keel

Asta Laugalienès research interests are areal linguistic contacts with a special focus on the notion of partitivity in Fennic and Baltic. asta.laugaliene@flf.vu.It 